\title{
Molecular disparities among Botrytis species involved in onion umbel blight disease and its management using Bacillus subtilis PHYS7
}

\author{
Kamal A. M. Abo-Elyousr ${ }^{1,2^{*}}$ (D, Saad A. M. Alamri, ${ }^{3,4}$, Mohamed M. A. Hussein ${ }^{5}$, Mohamed A. H. Hassan?',
} Bahaa E. S. Abd El-Fatah ${ }^{6}$ and Mohamed Hashem ${ }^{3,7}$

\begin{abstract}
A study of molecular variation among Botrytis spp., the causal pathogen of scape and umbel blights of onion, as well as the biocontrol of the virulent pathogen using Bacillus subtilis PHYS7 under greenhouse conditions was carried out. Twenty-three isolates of Botrytis spp. were recovered from onion plants showing umbel blight symptoms. They were able to infect onion plants with varied severity. All Botrytis spp. produced cellulases; however, almost all of them produced pectinase. The highest activities of cellulases and pectinase were achieved by B. allii PHYOA1; however, B. cinerea PHYOC3 showed a high activity of cellulases but it failed to produce pectinase. The genetic variability among the pathogens was assessed by random amplified polymorphic DNA (RAPD) markers, using 5 random 10-mer primers: OPA03, OPA05, OPA06, OPI09, and OPW15. The results showed that 50 DNA bands ranging from $100 \mathrm{bp}$ (OPA03) to $1600 \mathrm{bp}$ (OPA05) were generated by the 5 primers that differentiated 9 isolates of Botrytis spp. The dual culture test showed that Bacillus subtilis PHYS77 and PHYS78 had a high antagonistic potentiality against the pathogen and involved in 60-62\% reduction in its growth. Application of Ridomil Gold MZ and Bacillus subtilis PHYS77 on onion plants, 2 days after or before infection with the pathogen, significantly reduced the disease severity than the control. The study approved the molecular tool as a reliable and quick method to differentiate among the virulent and non-virulent strains of Botrytis spp. The application of $B$. subtilis PHYS77 as an effective biocontrol agent in the management of the onion blight disease can be recommended.
\end{abstract}

Keywords: Onion umbel blight, Biological control, Botrytis spp., Cellulases, Pectinase RAPD markers

\section{Background}

Several fungal, bacterial, nematode, and viral diseases attack onion (Allium cepa L.) during all stages of its production season. Among the fungal diseases, Botrytis byssoidea and $B$. allii the causal pathogens of umbel blight of onion are destructive pathogens that involved in a great reduction in the productivity. The umbel blight disease is an important disease that attacks the plant during the production of the seeds and could

\footnotetext{
* Correspondence: kaaboelyousr@agr.au.edu.eg

${ }^{1}$ Plant Pathology Department, Faculty of Agriculture, Assiut University, Assiut 71526, Egypt

${ }^{2}$ Faculty of Meteorology, Department of Arid Land Agric., Environ. and Arid Land Agriculture, King Abdulaziz University, Jeddah, Saudi Arabia Full list of author information is available at the end of the article
}

devastate the unprotected crops up to 70\% (Hussein et al., 2018). Spores of B. byssoidea, B. allii, B. porri, and $B$. squamosa cause infection for seedlings of green and bulb onions (Hussein et al., 2018). du Toit et al. (2004) reported the 4 diseases associated with onion seed crops causing blighting seed stalks and umbel and flower blight.

Molecular techniques based on the polymerase chain reaction (PCR) have been used as a tool in genetic mapping, evolutionary studies, molecular taxonomy, and diagnosis of several fungal species (Raja et al., 2017 ). Several workers have grouped Botrytis spp. population from different plant hosts using RAPD analysis and suggested that random amplified polymorphic DNA (RAPD) markers can be a reliable alternative for differentiating isolates of Botrytis spp. 
(Moyano et al., 2003). They reported that RAPD technology is suitable for studying the genetic structures of $B$. cinerea populations, generating and providing a better explanation of the genetic relationships among $B$. cinerea populations. This RAPD step is a powerful tool for grouping isolates and after more procedures can diagnose $B$. cinerea in plants, and may be useful to enhance knowledge of the epiphytology of the pathogen under field conditions (Rigotti et al., 2002). Although the management of these diseases depends on chemical fungicides, there are strong scientific demands to reduce the use of fungicides and the consequent environmental pollution and their residual toxicity (Alamri et al., 2019). Conducting environmentfriendly control methods for the management of plant disease is a critical worldwide strategy (Abo-Elyousr et al., 2019). One of the promising trends in biocontrol of plant diseases is the application of antagonistic microorganisms (Abdel-Rahim and Abo-Elyousr 2018).

The objective of this study was to differentiate the molecular variations among different isolates of the causal pathogen of onion umbel blight disease Botrytis spp. by RAPD technique. The virulent isolates of the pathogen were bio-controlled by application of Bacillus subtilis PHYS77 under greenhouse conditions.

\section{Materials and methods}

\section{Isolations of the causal pathogens}

Twenty-three isolates of Botrytis spp. were isolated from naturally diseased onion plants showing symptoms of $\mathrm{Bo}$ trytis Onion Umbel Blight (BOUB), collected from different onion seed producing farms, Assiut, Egypt (Hussein et al., 2018). Onion leaves, showing disease symptoms, were cut in small pieces, sterilized for 2 min in $2 \%$ sodium hypochlorite solution then, plated onto Potato Dextrose Agar (PDA) medium and incubated at $27^{\circ} \mathrm{C}$. After 4-5 days of incubation, the developing fungi were purified by a single spore technique on the same medium. The pure cultures of the isolated fungi were kept in refrigerator at $4{ }^{\circ} \mathrm{C}$ for further use.

\section{Pathogenicity test}

A pathogenicity test of Botrytis spp. isolates was carried out under greenhouse conditions. Inocula of the tested isolates were prepared by growing them on Petri plates (9$\mathrm{cm}$ diameter) containing PDA medium at $25^{\circ} \mathrm{C}$ for 15 days. Ten $\mathrm{ml}$ of sterile distilled water was added to each plate at the end of incubation period and the mycelial growth was carefully scraped with a sterile needle and used for inoculation of onion plants Cv Giza 6 that were grown in greenhouse at $20 \pm 2{ }^{\circ} \mathrm{C}$ during the day and $18 \pm$ $2{ }^{\circ} \mathrm{C}$ during the night. The onion bulbs were cultivated in pots (30-cm in diameter) filled with $5 \mathrm{~kg}$ sterilized sandy clay soil. Each pot was cultivated by one bulb of onion $\mathrm{CV}$ Giza 6 and cared to grow for 120 days, then they were used for to pathogenicity test experiment (Abo-Elyousr et al., 2008). Five replicates were used for each Botrytis isolate. Onion flower heads "umbels" of the plants were inoculated by spraying with a spore suspension of the fungus at a concentration of $10^{6} \mathrm{CFU} / \mathrm{ml}$. Ten $\mathrm{ml}$ of the spore suspension was applied for each treatment ( 5 plants) using a hand atomizer. After inoculation, plants were covered with polyethylene cage for $48 \mathrm{~h}$ to provide high moisture, then polyethylene opened partially, after $72 \mathrm{~h}$ the polyethylene was removed. Plants were kept under normal conditions until the appearance of the symptoms. Disease severity was noticed after 14 days from inoculation. It was recorded as the average percentage of infected seed-head or umbel area and readings were converted to disease severity using the following equation:

$$
\text { Disease severity } \%=[\Sigma(n \times V) / 4 \times N] \times 100
$$

where $n=$ number of seed-head umbels within each infection category, $N=$ total number of seed-stalk umbels examined, $V=$ numerical values of infection categories, and $4=$ constant, highest numerical value.

Scales of 0-4 were used by Hussein et al. (2007) as follows:

$0=$ No infection, $1=25 \%$ of seed-head umbel infected area, $2=50 \%$ of seed-head umbel infected area, $3=75 \%$ of seed-head umbel infected area, $4=100 \%$ of seed-head umbel infected area.

\section{Identification of the causal pathogens Morphological identification}

Morphological characteristics of mycelia and spores were used to identify the fungal isolates following identification references (Ellis and Waller, 1974; Yohalem et al., 2003; du Toit et al., 2004 and Chilvers and du Toit, 2006) with aid of mycologist of Assiut University Mycological Center, Assiut, Egypt.

\section{Identification of Botrytis spp. using polymerase chain reaction-restriction fragment length polymorphism}

PCR detection and restriction fragment length polymorphism (RFLP) were used for identification of Botrytis spp. isolated from the infected onions. The following DNA primers for amplification and subsequent identification of 4 different Botrytis spp. were used, using sequenced characterized amplified regions (SCARS): BA1r: 5'-TGAGTGCTGGCGGAAACAAA-3' and BA2f: 5'GTGGGGGTAGGATGAGATGATG-3' .

Using a Polymerase Chain Reaction (PCR) assay, the primers amplify around $413 \mathrm{bp}$ DNA product from species. Restriction fragment length polymorphism (RFLP) analysis of the PCR amplicon was carried out using the restriction enzyme ApoI and $500 \mathrm{bp}$ ladder (New England Biolabs, Beverly, MA) (Nielsen et al., 2002). 


\section{Variations among the tested isolates of the causal pathogen \\ Cellulases productivity \\ Detection of exo-1.4 B-glucanase (C1)}

The ability of the pathogenic isolates to produce exo-1, 4 $ß$-glucanase (C1) was screened. The tested fungi were inoculated into $250 \mathrm{ml}$ Erlenmeyer's conical flasks containing $50 \mathrm{ml}$ of cellulase production medium, which had the composition: (g/l) L-asparagine 0.5 , yeast extract 0.5 , $(\mathrm{NH} 4)_{2} \mathrm{SO}_{4} \quad 0.5, \quad \mathrm{KCL} \quad 0.5, \quad \mathrm{KH}_{2} \mathrm{PO}_{4} \quad 1.0, \mathrm{CaCl}_{2} \quad 0.2$, $\mathrm{MgSO}_{4} .7 \mathrm{H}_{2} \mathrm{O} 0.2$, and cellulose microcrystalline 10 , as described by Luo et al. (1997). The pH was adjusted to 7.0, using acetate buffer and the medium was incubated at 28 $\pm 1{ }^{\circ} \mathrm{C}$ for $7 \mathrm{~d}$ under static conditions. The growing medium was filtrated, using a filter paper Whatman No 1 , the mycelial mats were excluded, and the filtrate was considered as a crude enzyme. A well $(0.5 \mathrm{~cm}$ in width and $0.4 \mathrm{~cm}$ in depth) in the agar medium (had the same composition as mentioned above) was filled with $100 \mu \mathrm{l}$ of the filtrated crude enzyme, and the plates were incubated at $28^{\circ} \mathrm{C}$ for $24 \mathrm{~h}$. Then, the plates were flooded with $1 \%$ iodine solution ( $1 \mathrm{~g}$ iodine $+3 \mathrm{~g} \mathrm{KI}+100 \mathrm{ml}$ water) and shaken for $5 \mathrm{~min}$, the iodine solution was decanted. The clear zone around wells indicated positive for cellulase production by the releasing exo-1, $4-\beta$-glucanase $(\mathrm{C} 1)$. The activity of the enzyme was identified by measuring the diameter of the clear zone around the wells in $\mathrm{mm}$.

\section{Detection of endo-1.4 B-glucanase (CX)}

Twenty-three isolates of the pathogen were screened for their ability to produce endo-1, 4 3 -glucanase $(\mathrm{Cx})$ according to (Oksanen et al., 2000).

\section{Pectinase productivity}

The method was carried out as described by Hankin et al.(1971). The used medium contained the following constituents, which were prepared in 2 main portions (g/ l):

Portion A: Yeast extracts $(1 \mathrm{~g})$, pectin from citrus peel $(5 \mathrm{~g})$, Agar (15 g), distilled water $(500 \mathrm{ml})$, and its $\mathrm{pH}$ was adjusted to 7.0. Portion B: Mineral salt solution composition (per liter) of: $\mathrm{KH}_{2} \mathrm{PO}_{4}(4 \mathrm{~g}),\left(\mathrm{NH}_{4}\right)_{2} \mathrm{SO}_{4}(2 \mathrm{~g}), \mathrm{Na}_{2}$ $\mathrm{HPO}_{4}(6 \mathrm{~g}) \mathrm{CaCl}_{2}(1 \mathrm{mg}), \mathrm{CuSO}_{4}(50 \mu \mathrm{g}), \mathrm{H}_{3} \mathrm{PO}_{4}(10 \mu \mathrm{g})$, $\mathrm{MnSO}_{4}(10 \mu \mathrm{g}), \mathrm{ZnSO}_{4}(70 \mu \mathrm{g}), \mathrm{FeSO}_{4} .7 \mathrm{H}_{2} \mathrm{O}(1.0 \mathrm{mg})$, $\mathrm{MoO}_{3}(10 \mu \mathrm{g})$, distilled water $(500 \mathrm{ml})$ and $\mathrm{pH}$ was adjusted to 7.4.

The two portions were mixed thoroughly after autoclaving at $121^{\circ} \mathrm{C}$ for $15 \mathrm{~min}$. The pathogenic isolates were cultured into $250 \mathrm{ml}$ Erlenmeyer's conical flasks containing $50 \mathrm{ml}$ broth medium for each and incubated at $28^{\circ} \mathrm{C}$ for 7 days. A medium with the same composition (as above) solidified with agar was dispensed into 9-cm Petri dishes ( $20 \mathrm{ml}$ per plate); and the Petri dishes were then inoculated with the crude enzyme filtrate in $1 \mathrm{~cm}$ diameter wells and incubated for $24 \mathrm{~h}$ at $28^{\circ} \mathrm{C}$. After the incubation period, the dishes were flooded with $1 \%$ iodine solution, the excess of iodine was poured off from the plates. The appearance of the clear zone around wells indicates the production of pectinase enzyme (Ammar et al., 1995). The activity of the enzyme was evaluated by measuring the clear zone around the wells in $\mathrm{mm}$.

\section{Molecular dissimilarities among the causal pathogens using random amplified polymorphic DNA}

1. Cultivation of the fungal strains for DNA isolation

The pathogenic fungi were inoculated into $50 \mathrm{ml}$ of potato dextrose broth in 250-ml flasks. The flasks were incubated for $7 \mathrm{~d}$ at $27^{\circ} \mathrm{C}$, and the medium was filtered through a Buchner funnel after incubation, the mycelia were washed thoroughly twice with sterilized distilled water. Hundred mg of the obtained mycelia was used for DNA isolation as described by Cenis (1992).

2. Random amplified polymorphic DNA of Botrytis spp.

Nine isolates of Botrytis spp. were selected for amplification of the random polymorphic DNA. The 9 isolates were selected out the 23 isolates based on their source and their disease severity (low, medium and high). The selected isolates were B. squamosa PHYOQ 1, B. allii PHYOA1, B. allii PHYOA3 B. allii PHYOA5 B. allii PHYOA7, $B$. cinerea $\mathrm{PHYOC2}$, B. cinerea PHYOC3, B. aclada PHYOL1 and B. aclada PHYOL2. PCR amplification of genomic DNA was performed using 5 arbitrary primers set (Table 1) purchased from Operon Technologies (Alameda, CA). Amplification reactions were carried out in $25 \mu \mathrm{l}$ reaction volumes containing $40 \mathrm{ng}$ of purified fungal DNA and 10 pmol of primer. The reaction mixture contained $400 \mu \mathrm{M}$ of each dNTP, $2.5 \mathrm{mM} \mathrm{MgCl}{ }_{2}$, $1 \mathrm{x}$ reaction buffer and 1 unit of DNA polymerase (BioFlux cat. BSA12M1). The volume was adjusted to $25 \mu \mathrm{l}$ by the addition of sterile distilled water. Amplification was performed in a MJ research PTC-200 thermal cycler, with an initial

Table 1 Sequences of 10 mer arbitrary primers used in RAPDPCR

\begin{tabular}{lll}
\hline No. & Primer name & Sequence $5^{\prime} \rightarrow 3^{\prime}$ \\
\hline 1 & OPA03 & AGTCAGCCAC \\
2 & OPA05 & AGGGGTCTTG \\
3 & OPA06 & GGTCCCTGAC \\
4 & OPA09 & GGGTAACGCC \\
5 & OPA15 & TTCCGAACCC \\
\hline
\end{tabular}


denaturation at $94{ }^{\circ} \mathrm{C}$ for $4 \mathrm{~min}$, followed by $35 \mathrm{cy}$ cles each of denaturation at $94^{\circ} \mathrm{C}$ for $60 \mathrm{~s}$, annealing at $35^{\circ} \mathrm{C}$ for $60 \mathrm{~s}$ and extension at $72^{\circ} \mathrm{C}$ for $120 \mathrm{~s}$. A final extension at $72^{\circ} \mathrm{C}$ for $7 \mathrm{~min}$, then samples were cooled and held at $4{ }^{\circ} \mathrm{C}$ until use. PCR products were loaded into a $1.5 \%$ agarose gel in $1 \times \mathrm{TE}$ containing ethidium bromide at 100 volts, constant voltage for $3 \mathrm{~h}$. The electrophoresis gels were observed and photographed under a UV transilluminator by using a Herolab gel-documentation system model Mididoc (Herolab, Germany).

\section{Biological control of the disease under greenhouse conditions}

\section{Source of the bioagents}

Five bacterial isolates, Bacillus subtilis PHYS77, B. subtilis PHYS78, B. subtilis PHYS79 and B. subtilis PHYS80, Pseudomonas fluorescence PHYPf were obtained from Plant Pathology Department, Faculty of Agriculture, Assiut University, Assiut, Egypt, and were tested to determine their antagonistic capability against B. allii PHYOA1 (the most virulent isolate).

\section{Antagonistic effect of bacterial isolates in vitro}

The bacterial bio-agents were screened under in vitro against $B$. allii PHYOA1 for their antagonistic activities, using dual culture method as described by Abo-Elyousr and Mohammed (2009).

\section{Pot experiments}

Pot experiments were carried out in a greenhouse and the inoculation of the pathogen within the plants was carried out as mentioned in pathogenicity test. B. subtilis PHYS77 was grown on NA medium in conical flasks each containing $100 \mathrm{ml}$ NA medium and incubated at $28{ }^{\circ} \mathrm{C}$ for 2 days. The cultures were centrifuged at 1500 $\mathrm{rpm}$ for $15 \mathrm{~min}$. The optical density $\mathrm{OD}_{600} \mathrm{~nm}$ of the $B$. subtilis PHYS77 suspension was adjusted to obtain $4 \times$ $10^{7} \mathrm{CFU} / \mathrm{ml}$, water. Ten $\mathrm{ml}$ of the suspension was sprayed on onion plants, using a hand atomizer (Sallam Nashwa et al., 2009). Disease severity percentage was noticed after 14 d from inoculation according to Hussein et al. (2007). The fungicide "Ridomil gold MZ, mefenoxam $6 \%$ + copper oxide $60 \%$," at a concentration of $0.2 \%$ was used as a positive control.

\section{Statistical analysis}

Both greenhouse and lab experiments were carried out with 4 replicates/ treatment and the experiments were repeated twice. The laboratory treatments were arranged in a complete randomized design, while the greenhouse treatments were arranged in a completely randomized plot design. Analysis of variance was done, and the significance of differences among the treatments was determined according to the least significant difference (LSD) $P<0.05$ (Gomez and Gomez, 1984).

\section{Results and discussion}

\section{The causal pathogen of BOUD}

Occurrence of Botrytis onion umbel blight disease in Assiut, Egypt, was studied throughout the survey of many onion seed production areas. From diseased onion floral umbels, 23 fungal isolates were recovered. The results indicated that onion plants were heavily infected with the fungal pathogens. Recent studies reported that the cultivated area all over the world decreased as a result of infections by several pathogens that attack onion during growing seasons (Schwartz and Mohan, 2008). Five species of Botrytis were associated with bulb rots of onion and neck, umbel and affected onion crop productivity (Lorbeer et al., 2007). Botrytis allii, B. aclada, B. cinerea, $B$. byssoidea, and $B$. squamosa were described as the cause of sclerotial neck rot, mycelial neck rot, small sclerotial neck rot, and Botrytis Onion Umbel Blight (Langston and Saunders, 2009). Blighting of the umbels of onions by $\mathrm{Bo}$ trytis spp. was reported in Egypt by Abd-El-Razik et al. (1977). Also, Langston and Saunders (2009) reported that Botrytis squamosa, B. cinerea, and B. allii were involved in the flower blight of onion (Allium cepa L.).

\section{Identification of the causal pathogens Morphological identification}

Identification procedures of the 23 fungal isolates, recovered from naturally diseased onion heads, showing $\mathrm{Bo}$ trytis Onion Umbel Blight (BOUB) symptoms approved their classification as members of the genus Botrytis (Table 2) to confirm their association with the onion diseases. The 23 isolates belong to 4 species of Botrytis spp. Botrytis allii was represented by 13 isolates. Seven isolates were identified as $B$. cinerea and 2 isolates belonged to $B$. aclada, whereas $B$. squamosa was represented by one isolate. Higher isolation frequencies of both $B$. allii $(56.5 \%)$ and B. cinerea (30.5\%) confirm their potential as the main causal pathogens of the onion flower disease. The results are in agreement with Ellerbrock and Lorbeer (1977), who reported that B. cinerea and B. allii were isolated from flower blight, and they are the main causal agents for many diseases of onion flower as well as the findings of Langston and Saunders, 2009These species were frequently associated with onion neck rot (Chilvers and du Toit, 2006; Hafez et al., 2013 and Sayed et al., 2014), scape blight and bulb rot (Chilvers and du Toit, 2006), Botrytis leaf blight (Brankica Tanović et al., 2019), and leaf blast (Segall and Newhall, 1960). 
Table 2 Pathogenic capabilities of Botrytis spp. isolates on onion cultivar Giza 6 under open greenhouse conditions

\begin{tabular}{|c|c|c|c|}
\hline Isolate no. & Source of isolate & Pathogens & Disease severity (\%) \\
\hline 1 & Elfath, Assiut & B. allii PHYOA1 & 91.7 \\
\hline 2 & ElZawia, Assiut & B. allii PHYOA2 & 65.0 \\
\hline 3 & Reefa, Assiut & B. allii PHYOA3 & 58.9 \\
\hline 4 & Abo-Teeg, BniAdii, Assiut & B. allii PHYOA4 & 41.1 \\
\hline 5 & Abo-Teeg, Assiut & B. allii PHYOA5 & 77.8 \\
\hline 6 & Manfalout-EIAtamna, Assiut & B. allii PHYOA6 & 75.6 \\
\hline 7 & Manfalout & B. allii PHYOA7 & 25.0 \\
\hline 8 & Manfalout & B. allii PHYOA8 & 58.3 \\
\hline 9 & Reefa, Assiut & B. allii PHYOA9 & 46.7 \\
\hline 10 & Dirout, Assiut & B. allii PHYOA10 & 50.0 \\
\hline 11 & Durunka, Assiut & B. allii $\mathrm{PHYOA} 12$ & 71.7 \\
\hline 12 & Mangabad, Assiut & B. allii PHYOA12 & 52.2 \\
\hline 13 & Alghanaim, Assiut & B. allii PHYOA13 & 67.2 \\
\hline 14 & Abnoob, Assiut & B. cinerea PHYOC1 & 50.0 \\
\hline 15 & Mousha, Assiut & B. cinerea PHYOC2 & 66.7 \\
\hline 16 & Assiut & B. cinerea PHYOC3 & 83.3 \\
\hline 17 & El-Koussia, Assiut & B. cinerea PHYOC4 & 27.8 \\
\hline 18 & ArabElAwamer, Assiut & B. cinerea PHYOC5 & 47.2 \\
\hline 19 & Assiut Valley & B. cinerea PHYOC6 & 44.4 \\
\hline 20 & ArabElAwamer & B. cinerea PHYOC7 & 58.3 \\
\hline 21 & Dirout, Assiut & B. aclada PHYOL1 & 40.0 \\
\hline 22 & Abnoob-Elhamam, Assiut & B. aclada PHYOL2 & 33.3 \\
\hline 23 & Assiut Valley & B. squamosa PHYOQ 1 & 22.2 \\
\hline
\end{tabular}

Least significant difference LSD $(P<0.05)=6.18$

Molecular identification of the fungal pathogens using PCRRFLP

Application of PCR-RFLP was carried out, using the restriction enzyme ApoI and specific primers amplified an amplicon of Botrytis DNA, which produced $400 \mathrm{bp}$. This specific amplification was diagnostic and different among the $4 \mathrm{Bo}$ trytis spp. (Fig. 1). It was shown that B. squamosa had a specific band with $269 \mathrm{bp}, B$. aclada has a 413-bp band, $B$. allii has 2 bands $413 \mathrm{bp}$ and $298 \mathrm{bp}$, and $B$. cinerea has a 250-bp band. The molecular characterization, using PCRRFLP fitted well with the morphological characterization of the 4 species of Botrytis. These results matched the previous morphological identification and matched well with the results mentioned by Hafez et al. (2013).

PCR-RFLP is highly reproducible which makes it possible to predict genetic parameters more accurate and labor intensive (Raja et al., 2017). Previous reports on onion diseases caused by Botrytis spp. have not differentiated between $B$. aclada and B. allii, making it difficult to determine the relative distribution and significance of these 2 species as neck rot pathogens. However, since description of PCR and PCR-RFLP assay by Nielsen et al. (2002) for the primary neck rot B. allii, Botrytis spp. and B. aclada can be differentiated more readily; also Nielsen et al. (1999) collected 29 isolates from different countries and identified them morphologically as B. aclada or B. allii; however, when they applied the PCR-RFLP assay, they were separated into 3 species: B. byssoidea, B. squamosa, and B. allii (Nielsen et al., 2001 and Chilvers et al., 2004).

\section{Pathogenicity test}

Results indicated that all tested isolates of Botrytis spp. were able to infect onion plants causing Botrytis umbel blight disease (BOUB) with varied disease severity (Table 2). Botrytis allii PHYOA1, B. cinerea PHYOC3, B. allii PHYOA5 and B. allii PHYOA6 were involved in the highest disease severity $(91.7,83.9,77.8$, and $75.6 \%$, respectively), while B. squamosa PHYOQ5 and B. allii PHYOA7 exhibited the lowest disease severity on onion umbels (22.2-25.0\%). The other isolates of the 4 species of Botrytis exhibited moderate severity of BOUB disease, ranged between $27.8-67.2 \%$. The variation in disease severity and virulence of the pathogens could be affected by climatic conditions in regions, where they were isolated. In a 


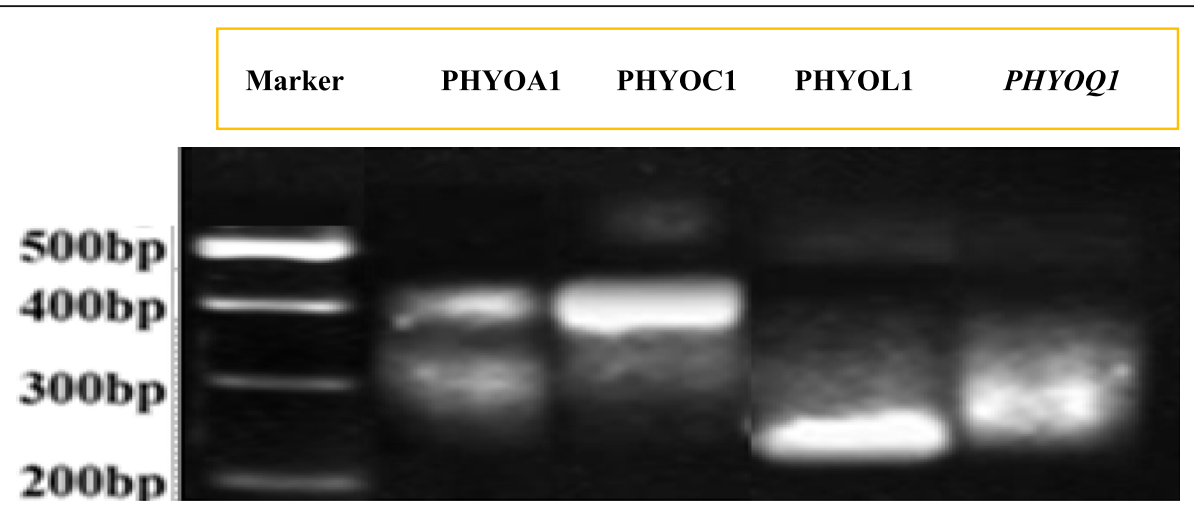

$\mathrm{PHYOA} 1=$ B. allii $\mathrm{PHYOA}, \mathrm{PHYOC} 1=$ B. cinerea $\mathrm{PHYOC} 1, \mathrm{PHYOL} 1=$ B. aclada $\mathrm{PHYOL} 1$,

PHYOQ1 = B. squamosa PHYOQ1

Fig. 1 PCR-RFLP analysis of four Botrytis spp. isolated from onion infected umbels

previous study, Shoemaker and Lorbeer (1977) reported that the free moisture is necessary for infection of umbel blight of onion by B. allii, B. cinerea, and B. squamosa. Similarly, Brankica Tanović et al. (2019) observed that temperature and moisture are the main factors that affect the pathogenicity of Botrytis spp. on the umbel of onions.

\section{Variations in enzyme activity among the tested Botrytis spp.}

Cellulase production The results indicated that most potent isolates were B. allii PHYOA1, B. allii PHYOA5, $B$. cinerea PHYOC3, and $B$. cinerea PHYOC2, whereas they showed the highest level of Exo-1, 4- $\beta$ - glucanase (C1) on cellulase production medium. The enzyme activity of the 4 organisms was measured as $16-18 \mathrm{~mm}$ (Table 3). The rest of the fungal isolates showed a moderate to low activity (up to $12 \mathrm{~mm}$ of clear zone). Botrytis allii PHYOA1, $B$. allii PHYOA 5, B. allii PHYOA11, $B$. cinerea PHYOC3, and $B$. cinerea $\mathrm{PHYOC7}$ were recorded as good producers of endo-1,4- $\beta$-glucanase $(\mathrm{Cx})$, where the clear zone ranged from 22 to $18 \mathrm{~mm}$ on cellulase production medium, while the other isolates showed low activity of endo-1,4- $\beta$-glucanase (Cx) (Table 3). Interestingly, B. allii PHYOA1 was among the isolates having the capabilities to produce a high amount of cellulase enzymes, involved in high disease severity on onion plants. The fungal isolates, which were characterized by moderate or low virulence on onion plants, showed a low productivity of cellulase. The assumption that disease severity of the pathogen could be related to its capacity to produce cellulases was supported by the findings of Chen et al. (2018).

Pectinase production The results indicated that $B$. allii PHYOA1 and B. allii PHYOA5 had the highest activity
Table 3 Cellulases and pectinase production of Botrytis species of onion in vitro

\begin{tabular}{|c|c|c|c|}
\hline \multirow[t]{2}{*}{ Isolates } & \multicolumn{2}{|c|}{ Cellulases (mm) } & \multirow{2}{*}{$\begin{array}{l}\text { Pectinase } \\
(\mathrm{mm})\end{array}$} \\
\hline & $\mathrm{C} 1$ & $C x$ & \\
\hline B. allii $\mathrm{PHYOA} 1$ & $18^{*}$ & 22 & $19^{*}$ \\
\hline B. allii PHYOA2 & 12 & 16 & 10 \\
\hline B. allii $\mathrm{PHYOA} 3$ & 10 & 14 & -ve \\
\hline B. allii PHYOA4 & 10 & 16 & 13 \\
\hline B. allii PHYOA5 & 16 & 22 & 15 \\
\hline B. allii PHYOA6 & 14 & 18 & 6 \\
\hline B. allii PHYOA7 & 10 & 10 & 11 \\
\hline B. allii PHYOA8 & 12 & 14 & 8 \\
\hline B. allii PHYOA9 & 12 & 12 & -ve \\
\hline B. allii PHYOA10 & 12 & 12 & 7 \\
\hline B. allii PHYOA11 & 12 & 20 & 17 \\
\hline B. allii PHYOA12 & 14 & 18 & 10 \\
\hline B. allii PHYOA13 & 14 & 16 & 6 \\
\hline B. cinerea PHYOC1 & 14 & 16 & 10 \\
\hline B. cinerea PHYOC2 & 16 & 16 & 11 \\
\hline B. cinerea PHYOC3 & 18 & 22 & -ve \\
\hline B. cinerea PHYOC4 & 12 & 12 & 12 \\
\hline B. cinerea PHYOC5 & 12 & 12 & 4 \\
\hline B. cinerea PHYOC6 & 14 & 12 & 9 \\
\hline B. cinerea PHYOC7 & 14 & 18 & 13 \\
\hline B. aclada PHYOL1 & 16 & 16 & 15 \\
\hline B. aclada PHYOL2 & 12 & 12 & 14 \\
\hline B. squamosa PHYOQ 1 & 12 & 12 & 17 \\
\hline
\end{tabular}

*Cleared zone caused by the isolate on the medium was measured in $\mathrm{mm}$ 
of pectinase production, while $B$. allii PHYOA6 and $B$. allii PHYOA13 had the lowest production (Table 3). On the other hand, both $B$. allii PHYOA3 and $B$. allii PHYOA9 did not produce any detectable amounts of pectinase. Botrytis cinerea PHYOC4 and B. cinerea PHYOC7 had high activities of the enzyme, while $B$. cinerea PHYOC5 showed low one. The other strains produced considerable amounts of the enzyme than with B. allii PHYOA11. Obtained results showed that the productivity of pectinase by the fungi was correlated by their pathogenicity. Both B. allii PHYOA1 and B. squamosa PHYOQ1, which were characterized by their high activities of pectinase, were in a high disease severity on onion plants.

Polymorphism among Botrytis spp. causing BOUB disease using RAPD RAPD technique requires single oligonucleotides that able to produce multiple bands, using primers that can be used to generate a large number of fragments from different regions of the genome and multiple loci can be examined very quickly. Polymorphism and genetic similarity among 9 Botrytis spp., using 5 random 10-mer primers (OPA03, OPA05, OPA06, OPI09 and OPW15) were analyzed to investigate the genetic differences among pathogenic Botrytis spp. generated 50 DNA bands (Fig. 2) ranging from $100 \mathrm{bp}$ (OPA03) to $1600 \mathrm{bp}$ (OPA05). The genetic similarity (GS) among the species was analyzed, using the software package MVSP program (Nei and $\mathrm{Li}, 1979$ ). The genetic similarity among the nine isolates of Botrytis spp. ranged from 66.7 to $87.8 \%$. The highest similarity and shortest genetic distance were scored between $B$. allii PHYOA1 and B. allii PHYOA5; however, the lowest genetic similarity was found between $B$. squamosa PHYOQ1 and B. cinerea PHYOC2 (Fig. 2 and Table 4). The dendrogram tree of the nine isolates of Botrytis spp. resulting from the UPGMA clustering values, illustrated in Fig (2) and Table (4) revealed the relationship of the species (Fig. 3) based on the number of markers that were different between any given pair isolates. Cluster dendrogram based on similarity matrix and obtained with unweighted pair group method, using arithmetic means (UPGMA) showed that the 9 Botrytis spp. had a high similarity value among each other (0.706 to 0.878) (Fig. 3). Data indicated that B. allii PHYOA1 and B. allii PHYOA5 displayed the highest number of DNA fragments (43 bands), while $B$. cinerea $\mathrm{PHYOC} 2$ revealed the least number of bands (29 bands). These variations in the number of bands, amplified by different primers, were influenced by variable factors such as primer structure and number of annealing sites in the genome. Polymorphic bands were detected by all primers surveyed in all isolates of Botrytis spp. Out of 71 DNA-bands,
23 were conserved among all isolates tested, while 45 (63.3\%) were polymorphic. The monomorphic bands were constant bands and cannot be used to study the diversity, while polymorphic bands revealed differences and could be used to examine and establish systematic relationships among the genotypes.

Based on molecular markers with the aid of the RAPD-PCR technique, Botrytis spp. involved in infection of onion blight were easily differentiated. Such information may lead to the development of more reliable methods for early detection of pathogens in the field (Paplomatas et al., 2004). Generally, a total of 71 DNA bands ranged from $100 \mathrm{bp}$ (OPA03) to $1600 \mathrm{bp}$ (OPA15) were generated by the 5 primers for the 9 isolates of Botrytis species. From the 71 bands obtained, 45 were polymorphic that revealed differences among the species and could be used to examine and establish systematic relationships among the genotypes. The highest number of amplified DNA fragments was detected for the primer OPA05, while the lowest number was amplified with the primer OPA05. $B$. allii PHYOA5 displayed the highest number of DNA fragments, while $B$. cinerea PHYOC2 revealed the least number of bands. Related previous work by Kerssies et al. (1997) who studied 29 isolates of Botrytis cinerea for correlation between their markers and pathogenicity and collected from inside and outside Dutch glasshouses, demonstrated that from 70 markers scored, few of them showed a high similarity. Cluster analysis recognized three groups. The presence of a unique band for a given genotype was taken as a positive marker, while the absence of a unique band referred as a negative marker. Such bands could be used as DNA markers for isolate identification and discrimination.

In this respect, the OPA03 primer showed specific positive bands for $B$. allii PHYOA1 and $B$. allii PHYOA5 that had the highest disease severity. This primer did not produce any detectable bands with $B$. squamosa PHYOQ1, B. cinerea PHYOC2 and $B$. aclada PHYOL2. Primer OPA09 produced specific positive bands for $B$. allii PHYOA3 with molecular weight (193 bp) and negative band at molecular weight $256 \mathrm{bp}$. Primer OPA06 showed two negative specific bands for $B$. allii PHYOA7 with molecular weight $347 \mathrm{bp}$ and $454 \mathrm{bp}$ and 2 positive specific bands with molecular weights of 411 and $175 \mathrm{bp}$, respectively. Primer OPA15 produced one positive and one negative specific band for $B$. allii PHYOA5 with molecular markers (326 and 534, respectively). These findings are significantly similar to those obtained by Martinez et al. (2003).

Most of RAPD-PCR specific markers were scored for isolate B. squamosa PHYOQ1, B. allii PHYOA1 


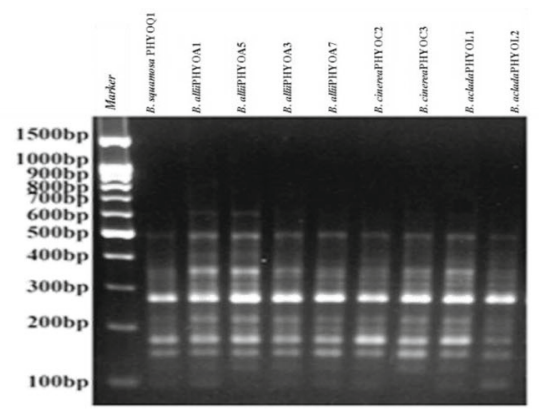

primer (OPA03)

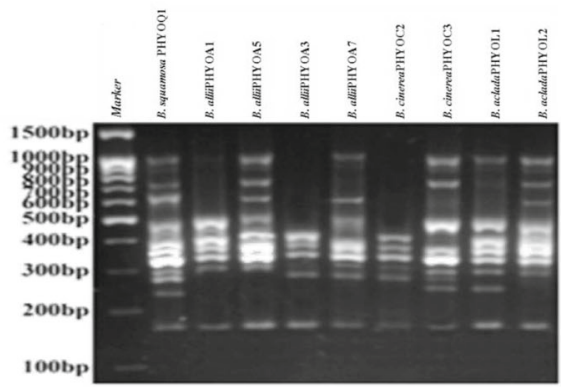

primer (OPA06)

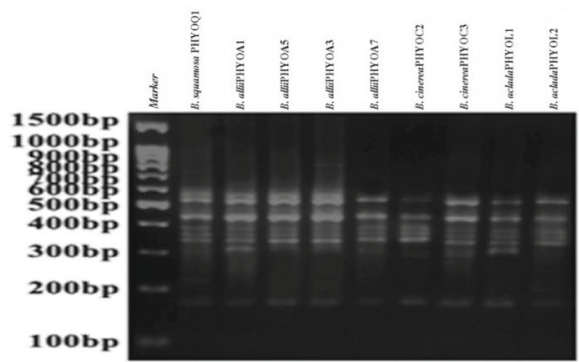

primer (OPA15)

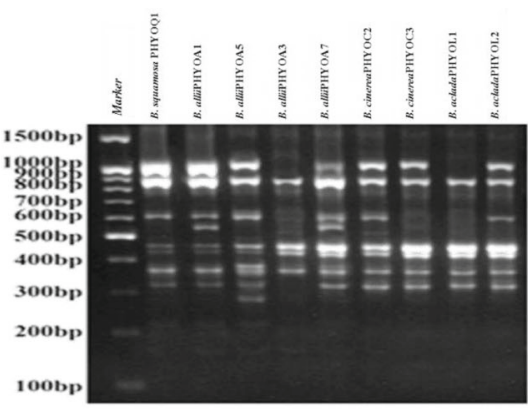

primer (OPA05)

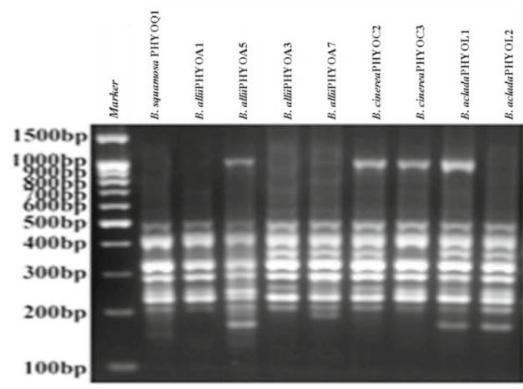

primer (OPA09)

Fig. 2 Agarose gel electrophoresis of RAPD-PCR primers OPA03, OPA05, OPA06, OPI09 and OPW15 profile of nine Botrytis spp. isolates

and B. allii PHYOA7. Obtained results indicated that 9 isolates-specific markers (7 positive and 2 negative) were detected and they could be used as markers for the investigated species. This study showed that there was a considerable genotypic variability among isolates of the 4 Botrytis spp. that were obtained from different geographic regions. This variation could be due to variations in geographical regions, where the climates are different or due to the disease severity of the isolates, which could be controlled by specific genes. These results are in line with those of Isenegger et al. (2008). The later assumption may be supported by the finding of Thompson and Latorre (1999) who mentioned that no relationship was found between geographical origins and the DNA profiles obtained from the study of B. cinerea in Chile. These results encourage to carry out further investigation on the molecular level to achieve more specific characterizations of the Botrytis spp. Our hypothesis is that the DNA fragment with molecular specific size can appear only in one unique isolate and can display high disease severity percentage and such band may be closely related to high virulence or be a distinguisher to specific pathogen. 
Table 4 Genetic similarity values calculated from total DNA fragments generated with five primers in nine Botrytis spp.

\begin{tabular}{|c|c|c|c|c|c|c|c|c|c|}
\hline Similarity matrix & $\begin{array}{l}\text { B. squamosa } \\
\text { PHYOQ1 }\end{array}$ & $\begin{array}{l}\text { B. allii } \\
\text { PHYOA1 }\end{array}$ & $\begin{array}{l}\text { B. allii } \\
\text { PHYOA5 }\end{array}$ & $\begin{array}{l}\text { B. allii } \\
\text { PHYOA3 }\end{array}$ & $\begin{array}{l}\text { B. allii } \\
\text { PHYOA7 }\end{array}$ & $\begin{array}{l}\text { B. cinerea } \\
\text { PHYOC2 }\end{array}$ & $\begin{array}{l}\text { B. cinerea } \\
\text { PHYOC3 }\end{array}$ & $\begin{array}{l}\text { B. aclada } \\
\text { PHYOL1 }\end{array}$ & $\begin{array}{l}\text { B. aclada } \\
\text { PHYOL2 }\end{array}$ \\
\hline $\begin{array}{l}\text { B. squamosa } \\
\text { PHYOQ1 }\end{array}$ & 1 & & & & & & & & \\
\hline B. allii PHYOA1 & 0.706 & 1 & & & & & & & \\
\hline B. allii PHYOA5 & 0.761 & 0.774 & 1 & & & & & & \\
\hline B. allii $\mathrm{PHYOA} 3$ & 0.675 & 0.744 & 0.753 & 1 & & & & & \\
\hline B. allii PHYOA7 & 0.723 & 0.786 & 0.725 & 0.711 & 1 & & & & \\
\hline $\begin{array}{l}\text { B. cinerea } \\
\text { PHYOC1 }\end{array}$ & 0.737 & 0.701 & 0.714 & 0.783 & 0.8 & 1 & & & \\
\hline $\begin{array}{l}\text { B. cinerea } \\
\text { PHYOC3 }\end{array}$ & 0.729 & 0.744 & 0.753 & 0.692 & 0.738 & 0.753 & 1 & & \\
\hline $\begin{array}{l}\text { B. aclada } \\
\text { PHYOL1 }\end{array}$ & 0.667 & 0.756 & 0.719 & 0.703 & 0.775 & 0.74 & 0.878 & 1 & \\
\hline $\begin{array}{l}\text { B. aclada } \\
\text { PHYOL2 }\end{array}$ & 0.78 & 0.747 & 0.756 & 0.693 & 0.79 & 0.757 & 0.747 & 0.759 & 1 \\
\hline
\end{tabular}

\section{Biological control of the BOUB disease}

Antagonistic effect of bacterial isolates in vitro $\mathrm{Re}$ sults of in vitro test (Fig. 4) showed that the 3 tested bacteria reduced the mycelial growth of $B$. allii PHYOA1. The highest inhibition percentage was scored by B. subtills PHYS77 and B. subtills PHYS78 (62 and 60\%, respectively), followed by B. subtilis PHYS79 and B. subtilis PHYS80 (48 and 46\%), while Pseudomonas fluorescence recorded the lowest inhibition percentage of the mycelia growth PHYPf1 (45\%). According to the above results, the isolate PHYS77 was selected for greenhouse experiment. The biological control capacity of Bacillus spp. was reported because produced several antibiotics having a broad range of fungal inhibition. Antibiotic production as a mode of action of Bacillus pp. was established and reported in previous studies (Alamri et al., 2019).

Suppression of disease severity of BOUB under greenhouse conditions The results indicated that antagonist B. subtilis PHYS77 reduced the disease severity, when it was applied before or after infection with the pathogen to 64.7 and $60.1 \%$, respectively compared to 94.4 $0 \%$ resulted from chemical fungicide (Ridomil Gold MZ) application under greenhouse conditions (Table 5). The results obtained here were very promising to apply the bacterial strains as a biological agent alternative to the fungicides in the management of such disease as a single application or as a part of the integrated management program (IPM). In accordance with our results, Botrytis spp. the causal pathogens of BOUB disease, was managed biologically

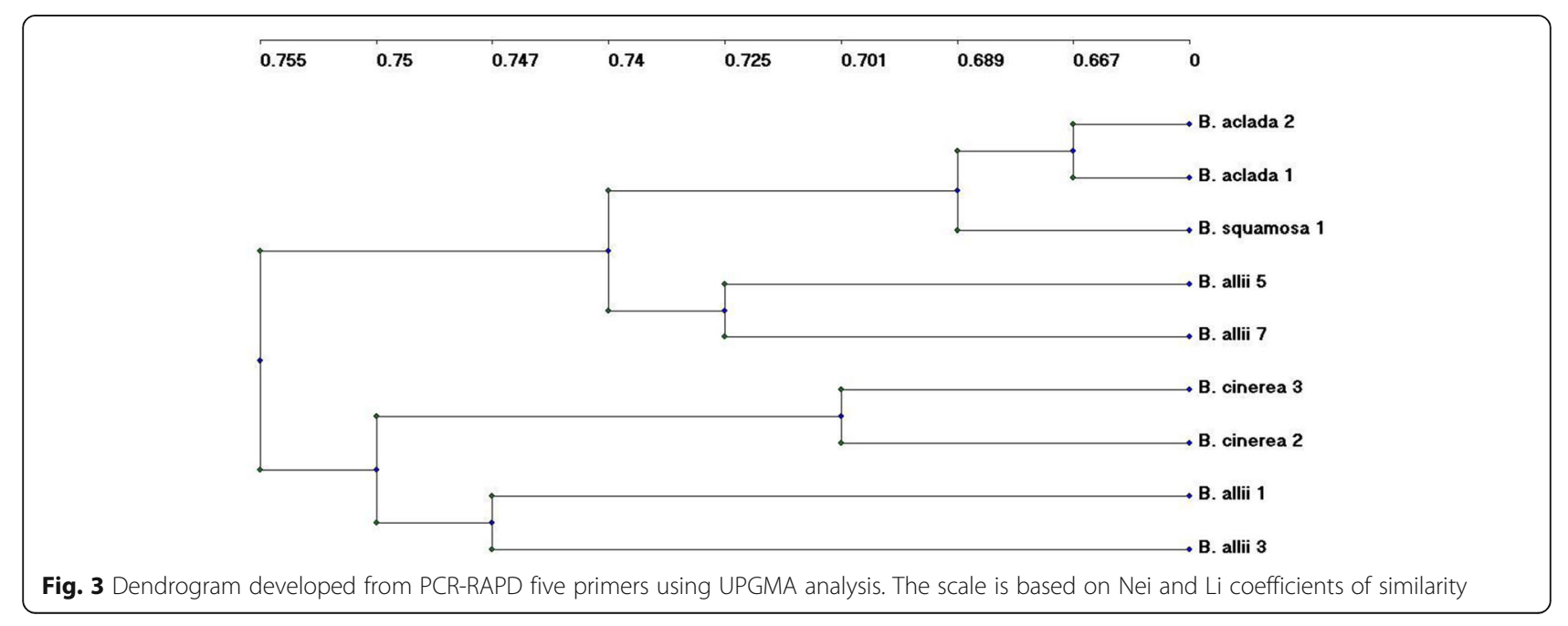




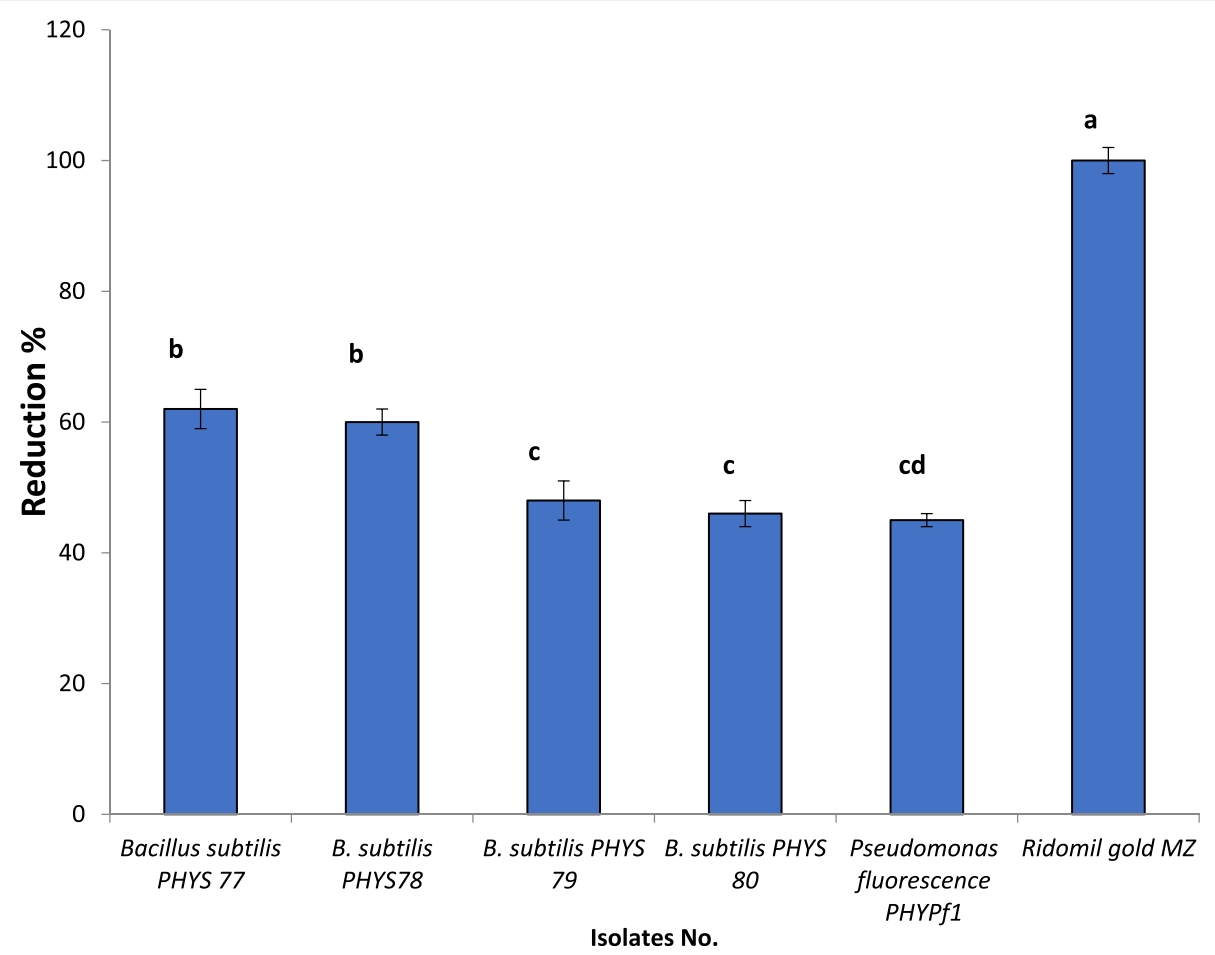

Fig. 4 Evaluation of inhibitory effect of certain bacterial isolates against B. allii PHYOA1 in vitro. Values on the column followed by a similar letter are not significantly different as determined by the LSD test $(P<0.05)$

by different antagonistic bacteria (Abo-Elyousr et al., 2014). B. subtilis as a good antagonistic microorganism was reported by its variable mechanisms of action against many fungal pathogens (Alamri et al., 2019; Punja et al., 2019 and Grata et al., 2019). B. subtilis produces bacteriocins that play an important role in essential host immunity (Hashem et al., 2019). Also, it may have indirect mechanisms against plant pathogens including, competition for nutrients, plant growth promotion, biofilm formation, and colonization sites, induced systemic resistance (ISR) (Wang et al., 2018). Activation of the induced resistance in plants by $B$. subtilis was known before (Garcia-Gutierrez et al., 2013) via induction the synthesis of ethylene and jasmonic acid (JA). Other strains belonging to the Bacillus spp. were well documented to produce an auxin (IAA) (Abo-Elyousr et al., 2019) and can retain more soil organic nitrogen and other nutrients in the plant. It has also been known to produce compounds, which promote plant growth directly or indirectly.

\section{Conclusion}

The study concludes that Botrytis onion umbel blight (BOUB) is a complex disease that could be caused by many pathogens as at least 4 Botrytis spp. were identified. Results suggest that application of RAPD technique by using specific primers can be utilized as a simple and quick diagnostic technique for pre-diagnosis of onion infection with Botrytis spp. to avoid their destructive effect at the flowering stage. As an ecofriendly management of the BOUB, the study recommends the application of the bioagent B. subtilis PHYS77 to reduce the disease severity and protect the plants during the growing season.

Table 5 Effect of treatment with Bacillus subtilis PHYS77 on disease severity \% of BOUB caused by B. allii PHYOA1 under greenhouse conditions

\begin{tabular}{lllllll}
\hline \multirow{2}{*}{ Treatment } & \multicolumn{2}{l}{ Treatments before infection } & & \multicolumn{2}{l}{ Treatments after infection } \\
\cline { 2 - 3 } & Disease severity (\%) & Disease reduction (\%) & & Disease severity (\% & Disease reduction (\%) & Disease severity (mean \%) \\
\hline Bacillus subtilis PHYS77 & $31.7 \mathrm{~b}$ & 64.7 & $35.0 \mathrm{~b}$ & 60.1 & $33.35 \mathrm{~b}$ \\
Ridomil gold MZ & $5.00 \mathrm{C}$ & 94.4 & $5.00 \mathrm{c}$ & 94.3 & $5.00 \mathrm{c}$ \\
Infected control & $90.0 \mathrm{a}$ & 0.00 & $87.8 \mathrm{a}$ & 0.0 & $88.9 \mathrm{a}$ \\
\cline { 1 - 2 }
\end{tabular}

Values in the column followed by a similar letter are not significantly different as determined by the LSD test $(P<0.05)$ 


\section{Acknowledgments}

The authors would like to express their gratitude to the Research Center of Advanced Materials - King Khalid University, Saudi Arabia, for the support through grant number RCAMS/KKU/002-19.

\section{Authors' contributions}

KA participated in the planning and designing of the experiments, implementation of the experiments, and writing of the manuscript. AS bacterial identification, analyzing data. MH participated in the planning and implementation of the experiments, sampling, lab work, and writing the draft. $\mathrm{MH}$ participated in the planning and implementation of the experiments and writing the draft and $A B$ participated in the implementation of the experiments and sampling. MH lab work and collecting data and revised the manuscript. All authors read and approved the final manuscript.

\section{Funding}

This study was financially supported by the Research Center of Advanced Materials - King Khalid University, Saudi Arabia through grant number RCAMS/KKU/002-19.

\section{Availability of data and materials}

Not applicable.

\section{Ethics approval and consent to participate}

This manuscript is in accordance with the guide for authors available on the journal's website. Also, this work has not been published previously and is approved by all authors and host authorities.

\section{Consent for publication}

All authors approved the publication of the study.

\section{Competing interests}

The authors declare that they have no competing interests.

\section{Author details}

'Plant Pathology Department, Faculty of Agriculture, Assiut University, Assiut 71526, Egypt. 'Faculty of Meteorology, Department of Arid Land Agric., Environ. and Arid Land Agriculture, King Abdulaziz University, Jeddah, Saudi Arabia. ${ }^{3}$ College of Science, Department of Biology, King Khalid University, Abha 61413, Saudi Arabia. ${ }^{4}$ Research Center for Advanced Materials Science (RCAMS), King Khalid University, P.O. Box 9004, Abha 61413, Saudi Arabia. ${ }^{5}$ Faculty of Agriculture and Natural Resources, Plant Pathology Department, Aswan University, Aswan, Egypt. ${ }^{6}$ Genetic Department, Faculty of Agriculture, Assiut University, Assiut 71526, Egypt. ${ }^{7}$ Faculty of Science, Botany and Microbiology Department, Assiut University, Assiut, Egypt.

Received: 19 November 2019 Accepted: 5 January 2020 Published online: 14 January 2020

\section{References}

Abdel-Rahim I, Abo-Elyousr KAM (2018) Talaromyces pinophilus strain AUN-1 as a novel mycoparasite of Botrytis cinerea, the pathogen of onion scape and umbel blights. Microbiol Res 212-213:1-9

Abd-El-Razik A, Sellam M, Rushdi M (1977) Occurrence of blasting disease [fungal] of onion seed-head in Egypt. Egypt J Phytopathol 2:65-69

Abo-Elyousr KAM, Abdel-Hafez S, Abdel-Rahim I (2014) Isolation of Trichoderma and Evaluation of their Antagonistic Potential against Alternaria porri. J Pytopathol 162:567-574

Abo-Elyousr KAM, Bagy HMM, Hashem M, AMA S, Mostafa YS (2019) Biological Control of Tomato Wilt Caused by Clavibacter michiganensis subsp. michiganensis Using Formulated Plant Growth-Promoting Bacteria. Egypt J Biol Pest Cont 29:54

Abo-Elyousr KAM, Hussein MAM, Allam A, Hassan M (2008) Enhanced onion resistance against stemphylium leaf blight disease, caused by Stemphylium vesicarium, by di-potassium phosphate and benzothiadiazole treatments. Plant Pathol J 24:171-177

Abo-Elyousr KAM, Mohammed H (2009) Biological control of Fusarium Wilt in tomato by plant growth-promoting yeasts and rhizobacteria. Plant Pathol. J. 25:199-204
Alamri SAM, Hashem M, Moustafa YS, Nafady NA, Abo-Elyousr KAM (2019) Biological control of root rot in lettuce caused by Exserohilum rostratum and Fusarium oxysporum via induction of the defense mechanism. Biol. Control 128:76-84

Ammar M, Louboudy S, Azab M, Afifi M (1995) A new method for the estimation of fungal pectinase (s) using the pectin clearing zone (PCZ) technique and its application in food industries. Al-Azhar Bull Sci 6:325-339

Cenis J (1992) Rapid extraction of fungal DNA for PCR amplification. Nuc Acids Res 20(9):2380

Chen PH, Chen RY, Jui-Yu C (2018) Screening and Evaluation of Yeast Antagonists for Biological Control of Botrytis cinerea on Strawberry Fruits. Microbiology 46:33-46

Chilvers M, Pethybridge S, Hay F, Wilson C (2004) Characterisation of Botrytis species associated with neck rot of onion in Australia. Austr Plant Pathol 33: 29-32

Chilvers MI, du Toit LJ (2006) Detection and identification of Botrytis species associated with neck rot, scape blight, and umbel blight of onion. Plant Health Prog 10:1127-1134

du Toit L, Derie M, Pelter G (2004) Botrytis species associated with onion seed crops in Washington State. Plant Dis 88: 1061-1068.

Ellerbrock L, Lorbeer J (1977) Etiology and control of onion flower blight. Phytopathology 67:155-159

Ellis M, Waller J (1974) Sclerotinia fuckeliana (conidial state: Botrytis cinerea). CMI Descrebtion of Pathogen Fungi and Bacteria, Comm Myco Inst, UK (Kew) p. 507.

Gomez KA, Gomez AA (1984) Statistical Procedures for Agricultur Research, 2nd edn. John Willey, New York, 680 pp

Grata K, Rombel-Bryzek A, Ziembik Z (2019) Bacillus subtilis bs-2 and peppermint oil as biocontrol agents against Botrytis cinerea. Ecological Chemistry Engin 26(3):597-607

García-Gutiérrez L, Romero D, Zeriouh H, Cazorla FM, Torés JA, de Vicente A, Pérez-García A (2013) Isolation and selection of plant growth-promoting rhizobac-teria as inducers of systemic resistance in melon. Plant Soil 58: $201-$ 212

Hafez EE, Ramadan A, Abdel-Gayed M (2013) Molecular identification of four Botrytis species three of them associated with neck rot and blasting diseases of onion with special reference of two, aclada and byssoidae. J Pure Appl Microbiol 7:79-91

Hankin L, Zucker M, Sands D (1971) Improved solid medium for the detection and enumeration of pectolytic bacteria. Applied Microbiol 22:205-209

Hussein M, Hassan M, Allam A, Abo-Elyousr KAM (2007) Management of Stemphylium blight of onion by using biological agents and resistance inducers. Egypt J Phytopathol 35:49-60

Hussein MMA, Abo-Elyousr KAM, Hassan MA, Hashem M, Hassan EA, Alamri SAM (2018) Induction of defense mechanisms involved in disease resistance of onion blight disease caused by Botrytis allii Egypt. J Biol Pest Cont 28:80

Hashem A, Tabassum B, Elsayed Fathi AbdAlla. (2019) Bacillus subtilis: A plantgrowth promoting rhizobacterium that also impacts biotic stress. Saudi J. Biolog Scie 26:1291-1297.

Isenegger, D, Ades, P, Ford R, Taylor P (2000). Status of the Botrytis cinerea species complex and microsatellite analysis of transposon types in South Asia and Australia. Fungal Divers 29: 17-26.

Kerssies A, Bosker-van Zessen A, Wagemakers C, Van Kan J (1997) Variation in pathogenicity and DNA polymorphism among Botrytis cinerea isolates sampled inside and outside a glasshouse. Plant Dis 81:781-786

Langston D, Saunders FH (2009) Evaluation of fungicides and spray programs for foliar diseases of onions in Georgia. Plant Dis. Manage. Rep. 3:V145

Lorbeer JW, Seyb AM, de Boer M, van den Ende JE (2007) Botrytis species on bulb crops. Biology, Pathology and Control. Springer, Botrytis, pp 273-294

Luo J, Xia L, Lin J, Cen P (1997) Kinetics of simultaneous saccharification and lactic acid fermentation processes. Biotechnol Progress 13:762-767

Martinez F, Blancard D, Lecomte P, Levis C, Dubos B, Fermaud M (2003) Phenotypic differences between vacuma and transposa subpopulations of Botrytis cinerea. Eur J Plant Pathol 109:479-488

Moyano C, Alfonso C, Gallego J, Raposo R, Melgarejo P (2003) Comparison of RAPD and AFLP Marker Analysis as a Means to Study the Genetic Structure of Botrytis cinerea Populations. Eur J Plant Pathol 109:515-522

Nei M, Li WH (1979) Mathematical model for studying genetic variation in terms of restriction endonucleases. Proc the Nation Academy Scie 76:5269-5273

Nielsen $K$, Justesen AF, Jensen DF, Yohalem DS (2001) Universally primed polymerase chain reaction alleles and internal transcribed spacer restriction 
fragment length polymorphisms distinguish two subgroups in Botrytis aclada distinct from B. byssoidea. Phytopathology 91:527-533

Nielsen K, Justesen AF, Yohalem DS, Barba M (1999) PCR based detection of latent infections of Botrytis aclada Fres. in onion bulbs. Petria 9:105-108

Nielsen K, Yohalem DS, Jensen DF (2002) PCR detection and RFLP differentiation of Botrytis species associated with neck rot of onion. Plant Dis 86:682-686.

Oksanen T, Pere J, Paavilainen L, Buchert J, Viikari L (2000) Treatment of recycled kraft pulps with Trichoderma reesei hemicellulases and cellulases. J Biotechnol 78:39-48

Paplomatas E, Pappas A, Antoniadis D (2004) A Relationship among fungicideresistant phenotypes of Botrytis cinerea based on RAPD analysis. J Phytopathol 152:503-508

Punja ZK, Tirajoh A, Collyer D, Ni L (2019) Efficacy of Bacillus subtilis strain QST 713 (Rhapsody) against four major diseases of greenhouse cucumbers. Crop Protection 124:104845

Raja HA, Miller AN, Pearce CJ, Oberlies NHJ (2017) Fungal identification using molecular tools: A Primer for the Natural Products Research Community. Nat. Prod 80:756-770. https://doi.org/10.1021/acs.jnatprod.6b01085

Rigotti S, Gindro K, Richter H, Viret O (2002) Characterization of molecular markers for specific and sensitive detection of Botrytis cinerea Pers.: Fr. in strawberry (Fragaria ananassa Duch.) using PCR. FEMS Microbiol Let 209:169174

Sallam Nashwa MA, Abd Elrazik AA, Hassan M, Koch E (2009) Powder formulations of Bacillus subtilis, Trichoderma spp and Coniothyrium minitans for biocontrol of white rot of onion. Arch Phytopathol Plant Prot 42(2):142174

Sayed AA, Abd-El-Razik A, Abd-El-Rahman T, Eraky A (2014) Influence of certain carbon and nitrogen sources on antagonistic potentiality of Trichoderma harzianum and Bacillus subtillus against Botrytis allii the incitant of onion neck rot. J Phytopathol Pest Manag 1:9-16

Schwartz H, Mohan S (2008) Compendium of onion and garlic diseases and pests, American Phytopathological Society. (pp.145-151) APS Press, St. Paul.

Segall R, Newhall A (1960) Onion blast or leaf spotting by species of Botrytis. Phytopathology 50:76-82

Shoemaker P, Lorbeer J (1977) The role of dew and temperature in the epidemiology of Botrytis squamosa leaf blight of onion. Phytopathology 67: 1267-1272

Tanović B, Milan K, Jovana H, Milica M, Vojislav T, Delibašić G (2019) Botrytis squamosa - the causal agent of onion leaf blight in Bosnia and Herzegovina Pestic. Phytomed 34:9-17

Thompson J, Latorre B (1999) Characterization of Botrytis cinerea from table grapes in Chile using RAPD-PCR. Plant Dis 83:1090-1094

Wang X, Zhao D, Shen L, Jing C, Zhang C (2018) Application and Mechanisms of Bacillus subtilis in Biological Control of Plant Disease. Role of Rhizospheric Microbes in Soil Springer:225-250

Yohalem DS, Nielsen K, Nicolaisen M (2003) Taxonomic and nomenclatural clarification of the onion neck rotting Botrytis species. Mycotaxon 85:175-182

\section{Publisher's Note}

Springer Nature remains neutral with regard to jurisdictional claims in published maps and institutional affiliations.

\section{Submit your manuscript to a SpringerOpen ${ }^{\circ}$ journal and benefit from:}

- Convenient online submission

- Rigorous peer review

- Open access: articles freely available online

- High visibility within the field

- Retaining the copyright to your article

Submit your next manuscript at $\boldsymbol{\nabla}$ springeropen.com 